\title{
The Role of Chest X-Ray in Monitoring Lung Changes among COVID-19 Patients in Gaza Strip
}

\author{
Mahmoud Mousa1 ${ }^{\circledR}$, Marwan Matar'1, Yasser Al Ajerami², Ahmad Naijm³ ${ }^{3}$ Khalid Abu Shab', \\ Sadi Jaber ${ }^{4}$, Fouad SJaber5, Hazem Dawoud6
}

${ }^{1}$ Department of Radiology, Gaza-European Hospital, Gaza Strip, Palestine

${ }^{2}$ Department of Medical Imaging, Applied Medical Sciences, Al-Azhar University, Gaza Strip, Palestine

${ }^{3}$ Department of Nursing, Applied Medical Sciences, Al-Azhar University, Gaza Strip, Palestine

${ }^{4}$ Department of Radiology, Nasser Medical Complex, Gaza Strip, Palestine

${ }^{5}$ Valley Fever Institute, UCLA Kern Medical, Bakersfield, USA

${ }^{6}$ Department of Chemistry and Biochemistry, Ohio University, Athens, USA

Email: aboalsajed@gmail.com

How to cite this paper: Mousa, M., Matar, M., Al Ajerami, Y., Naijm, A., Shab, K.A., Jaber, S., SJaber, F. and Dawoud, H. (2021) The Role of Chest X-Ray in Monitoring Lung Changes among COVID-19 Patients in Gaza Strip. Open Journal of Medical Imaging, 11, 29-47.

https://doi.org/10.4236/ojmi.2021.112004

Received: March 8, 2021

Accepted: April 24, 2021

Published: April 27, 2021

Copyright $\odot 2021$ by author(s) and Scientific Research Publishing Inc. This work is licensed under the Creative Commons Attribution International License (CC BY 4.0).

http://creativecommons.org/licenses/by/4.0/

\section{(c) (i) Open Access}

\begin{abstract}
Objective: To investigate the time course and findings severity of COVID-19 infection at chest radiography based on a 6-point radiological severity score, and correlates these with patients' age and gender. Methods: This is a retrospective study of COVID-19 patients who were admitted at European Gaza Hospital and evaluated between October 6, 2020, and November 30, 2020. Baseline and serial chest radiographs, up to 4 images per patient, were reviewed and assessed for predominant pattern, side, and location of lung opacity. Utilized a 6-point scoring system, which divides the chest X-ray into 6 zones, to assess chest X-ray changes and correlate them with the severity of infection, age, and gender of patients. Results: The study included 136 COVID-19 patients: $(51 / 136,37 \%)$ were males and $(85 / 136,62.5 \%)$ were females, while age ranged from 7 months to 90 years with a mean age of $41.7 \pm$ (19.5) years. Negative Chest $\mathrm{x}$-rays were more observed than positive images. Ground-glass opacity was the most frequent pattern with a decreasing trend from 1st to 4 th chest X-ray (from $33.8 \%$ to $3.7 \%$ ), followed by consolidation (from $16.2 \%$ to $2.9 \%$ ). Also, the commonest pattern of opacity was seen in peripheral areas $(27 / 136,19.9 \%)$, lower zone location $(23 / 136,16.9 \%)$, and bilateral opacity involvement (43/136; 31.6\%). No significant correlation was noticed between the patient's gender, age, and severity score $(\mathrm{P}>0.05)$. Conclusions: The 6-point chest X-ray severity score as a predictive tool in assessing the severity due to provide an assessment of the progression or regression pathway.
\end{abstract}




\section{Keywords}

Chest X-Rays, COVID 19, Lung Changes, Scoring System, Gaza Strip

\section{Introduction}

The Coronavirus Disease 2019 (COVID-19), a novel worldwide pandemic, is a highly infectious disease-causing pathological lung changes that can result in severe pneumonia up to Acute Respiratory Distress Syndrome (ARDS) [1] [2]. Notably, the Gaza strip is an overcrowded populated zone that forms part of the occupied Palestinian territories and is inhabited by more than 2 million Palestinians of whom the majority are registered refugees living in jammed camps [3]. On August 24, 2020, the alarm at Gaza strip, Palestine was announced declaring several cases infected with COVID-19 within the community in Al-Maghazi refugee camp in the Mid-Zone Governorate [4]. Gradually, the spread of the virus progressed, with a total number of 37,842 confirmed cases as of December 27,2020 . Of these cases, 10,954 cases are still active cases receiving medical care in hospitals and isolation centers, 26,556 cases have fully recovered and were discharged, while the number of deaths reached 332 deaths [5]. Current coronavirus disease 2019 (COVID-19) radiological literature is dominated by CT findings [6] [7] [8] due to the higher sensitivity of CT more than chest radiography. However, this practice put an immense burden on radiology departments and placed a great challenge for infection control in the CT suite. Given the disturbance of CT service availability due to the required CT decontamination after scanning patients with COVID-19, the American College of Radiology suggests using portable chest radiography to decrease the risk of cross-infection [9]. Chest-X-ray is beneficial in monitoring the potential thoracic complications in critically ill patients with COVID-19 induced pneumonia [10]. While chest $\mathrm{X}$-rays are less detailed than computed tomography (CT) scans, they are quicker to perform, widely available and radiologists can still identify the lung changes as pneumonia [11], the main radiological feature of chest X-ray in COVID-19 [7] [12]. Accordingly, chest radiography cannot be replaced by CT scans in many countries during the current pandemic. Additionally, using chest X-ray for early disease recognition may also play a critical role in areas around the world with limited access to RT-PCR COVID testing [13]. Of note, a detailed description of chest X-ray changes in COVID-19 patients in correlation with the illness time course is lacking [14]. Toussie et al study investigated the use of 6-point chest radiography severity score as a prognostic indicator of outcomes in COVID-19 patients [15]. The purpose of this study was to monitor the radiological lung changes using the 6-point scoring system [15] and investigate the correlation of these changes with the time course of infection, and with the age and gender of COVID-19 patients. 


\section{Method and Materials}

\subsection{Design, Population, Setting, and Period of the Study}

This descriptive retrospective study included 136 COVID-19 cases and was conducted at European Gaza Hospital (EGH), an isolation hospital for COVID-19 cases in Gaza strip. The study population consisted of all COVID-19 patients who were admitted to the hospital from October 6, 2020, to November 30,2020 , and were examined by chest X-ray during the data collection period.

\subsection{The Inclusion and Exclusion Criteria for All Participants}

Inclusion criteria in this study were: patients' of any sex and age which RT-PCR nasopharyngeal-throat swab positive results hospitalized patients into a medicine department or an intensive care unit (ICU). Exclusion criteria in this study were: patients have thoracic spine congenital anomalies as scoliosis, chest $\mathrm{x}$-ray malrotation, and bad quality especially inadequacy of $\mathrm{x}$-ray exposure.

\subsection{Study Instruments and Data Collection Procedure}

All patients underwent chest radiography at admission, and follow-up chest radiographs were performed for patients with positive radiological findings, up to 4 images per patient. Tools for data collection include the Picture Archiving and Communication System (PACS), Digital Imaging and Communications in Medicine (DICOM) network system, radiant viewer, and questionnaire checklist. A chest $\mathrm{x}$-ray was performed in Anteroposterior (AP) or Posteroanterior (PA) projections by basic $(\mathrm{n}=111 / 136)$ or portable Shimadzu's $\mathrm{x}$-ray machine $(\mathrm{n}=$ 25/136), and the images were processed via AGFA CR 30-X digitizer-CR system.

The data were collected retrospectively via categorizing the date of chest $\mathrm{x}$-ray imaging. Radiographic features were diagnosed according to the Fleischner Society glossary of terms (28) and include consolidation, ground-glass opacities, pulmonary nodules, reticular opacities, and reticulonodular opacities. Consolidation opacity was further classified into lobar, diffuse, and multifocal. The distribution of the lung changes was categorized into peripheral predominance, central, or both; unilateral, or bilateral lung involvement; and middle zone, lower zone, mid and lower zone, or upper, mid, and lower zone. Manifestations of pleural effusion, pericardial effusion, and cardiomegaly were also recorded.

Chest $\mathbf{x}$-ray scoring system: The pathological lung changes were monitored and followed upusing a serial of chest X-rays up to 4 images per patient during the admission period (approximately 1 month). To facilitate the monitoring of radiological lung changes, we utilized the 6-point radiological severity score [15]. As Figure 1 shown, the scoreis designed to divide the chest $\mathrm{x}$-ray into six zones on AP or PA chest view. It is performed by drawing a vertical line on the mid of the thoracic spine dividing the chest in right and left. Then, two horizontal lines are drawn. The first one separates the upper zones, which are above the inferior wall of the aortic arch, from the middle zones, which are below the inferior wall 


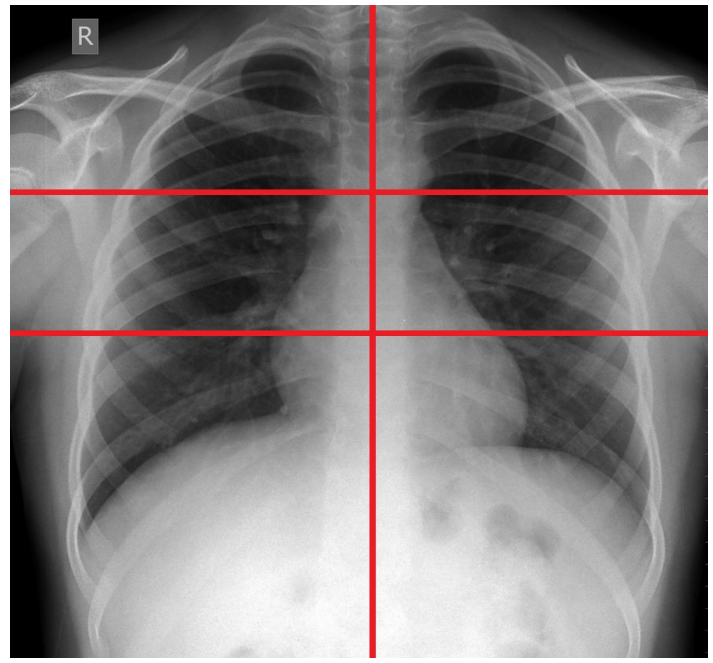

Figure 1. Illustration of chest X-ray with the 6-point radiological severity scoring system, which divides the lung into six zones.

of the aortic arch and above the inferior wall of the right inferior pulmonary vein (i.e., the hilar structures). The second horizontal line separates the middle zones from the lower zones, which are below the inferior wall of the right inferior pulmonary vein (i.e., the lung bases). Each zone was given a score depending on the presence of opacity, with (0) given for the absence of opacity and (1) for the presence of opacity. Subsequently, the score of each zone was summed for a total score [15]. This 6-points radiological severity score ranges from 0 to 6, with lower severity scores (mild opacity) ranges from 0 to 2, intermediate severity (moderate opacity) ranges from 3 to 4 , and high severity (severe opacity) ranges from 5 to 6 .

\subsection{Statistical Analysis}

Data were analyzed using the Statistical Package of Social Sciences (SPSS) system (Version 25). Descriptive statistics in the form of frequencies and percentages were employed. Also, cross-tabulation, independent t-test, and one-way ANOVA tests were applied. The confidence intervals (CI) were reported as $95 \%$ and a $\mathrm{P}$-value of less than 0.05 was considered statistically significant.

\subsection{Ethical and Administration Consideration}

The researchers got the ethical and administrative approval from the Helsinki committee and human resources development department administration respectively to conduct the study.

\subsection{Limitations of the Study}

AP images from portable machines produce poorer quality and some were missed because of the magnified heart and due to sub-optimal imaging quality given the patient's low inspiratory effort (possibly exacerbated by his illness). 


\section{Results}

\subsection{Patient Characteristic}

Table 1: Patient Characteristics at Presentation. This study reported 136 COVID-19 patients in which RT-PCR and chest X-rays were performed. Of

Table 1. Patient characteristics at presentation.

\begin{tabular}{|c|c|}
\hline Parameter & No. of Patients $(n=136)$ \\
\hline \multicolumn{2}{|l|}{ Age groups } \\
\hline$(0-12$ y) Child & $10(7.4 \%)$ \\
\hline (13 - 18 y) Adolescence & $12(8.8 \%)$ \\
\hline (19 - 59 y) Adult or middle age & $91(66.9 \%)$ \\
\hline$(60-90$ y) Old age & $23(16.9)$ \\
\hline \multicolumn{2}{|l|}{ Gender } \\
\hline Male & $51(37.5 \%)$ \\
\hline Female & $85(62.5 \%)$ \\
\hline \multicolumn{2}{|l|}{ Area } \\
\hline North Gaza & $82(60.3 \%)$ \\
\hline Gaza & $44(32.4 \%)$ \\
\hline Mid Zone & $5(3.7 \%)$ \\
\hline Khan Yunis & $2(1.5 \%)$ \\
\hline Rafah & $3(2.2 \%)$ \\
\hline \multicolumn{2}{|l|}{ Techniques } \\
\hline Basic $\mathrm{x}$-ray machine & $111(81.6 \%)$ \\
\hline Portable $\mathrm{x}$-ray machine & $25(18.4 \%)$ \\
\hline \multicolumn{2}{|l|}{ Patient state } \\
\hline Intubation & $3(2.2 \%)$ \\
\hline Not-intubation & $122(89.7 \%)$ \\
\hline Death & $10(7.4 \%)$ \\
\hline \multicolumn{2}{|l|}{ Patient care place } \\
\hline Hospital department & $123(90.4 \%)$ \\
\hline ICU & $13(9.6 \%)$ \\
\hline \multicolumn{2}{|l|}{ Previous history } \\
\hline Healthy & $66(48.5 \%)$ \\
\hline Chronic diseases & $70(51.5 \%)$ \\
\hline \multicolumn{2}{|l|}{ Severity of COVID 19 symptoms } \\
\hline Asymptomatic & $11(8.1 \%)$ \\
\hline Mild & $43(31.6 \%)$ \\
\hline Moderate & $31(22.8 \%)$ \\
\hline Severe & $51(37.5 \%)$ \\
\hline \multicolumn{2}{|l|}{ Clinical signs of the participants } \\
\hline Fever & $123(90.4 \%)$ \\
\hline Cough & $113(83.1 \%)$ \\
\hline Chills & $81(59.6 \%)$ \\
\hline Sore throat & $85(62.5 \%)$ \\
\hline Headache & $103(75.7 \%)$ \\
\hline Dyspnea & $104(76.5 \%)$ \\
\hline Loss of taste/smell & $88(64.7 \%)$ \\
\hline Muscles/Joint pain & $83(61 \%)$ \\
\hline Diarrhea & $85(62.5 \%)$ \\
\hline
\end{tabular}


those cases, $(51 / 136,37.5 \%)$ were males, and $(85 / 136,62.5 \%)$ were females while age ranged from 7 months to 90 years; with a mean age of $41.7 \pm$ (19.5) years. The most frequent age among patients was middle age (19 - 59 years) (91/136, $66.9 \%)$.

\subsection{Chest Radiography Features}

This study was conducted based on monitoring the lung changes using serial of images up to 4 radiographs per patient according to Figures 2-6. Their radiological finding and monitoring characteristics are summarized in Table 2.

\subsubsection{First Chest X-Ray Features Analysis}

In our study, the ground-glass opacity was the most common finding (46/136, $33.8 \%)$, followed by consolidation opacity $(22 / 136,16.2 \%)$. The Consolidation opacity was distributed by lobar $(9 / 136,6.6 \%)$, diffuse $(6 / 136,4.4 \%)$, and multifocal $(6 / 136,4.4 \%)$. Peripheral distribution was more commonly seen $(27 / 136$,

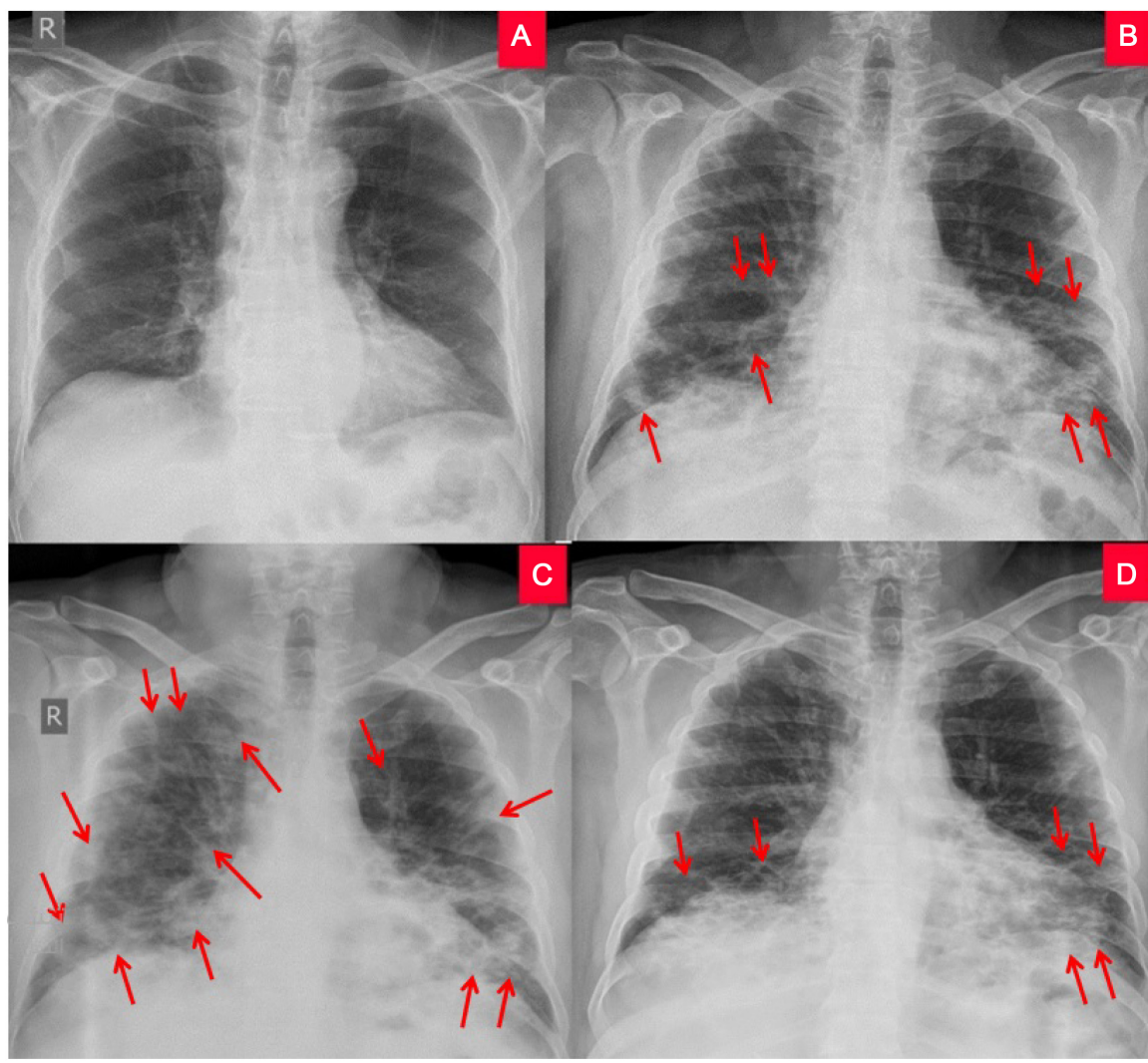

Figure 2. Series of chest $\mathrm{x}$-rays in a 48-year-old man with COVID-19. (A): PA chest X-ray obtained on day 1 illness shows negative radiological finding with score zero; (B): PA chest $\mathrm{X}$-ray obtained on day 5 illness shows bilateral mid and lower zone ground-glass opacity with central and peripheral lower zone consolidation with score 5 ; (C): PA chest $\mathrm{x}$-ray obtained on day 9 illness shows multifocal bilateral nodular and patchy consolidation at upper, mid, and lower zones with score 5; (D): PA chest x-ray obtained on day 17 illness shows the dissipative stage with regression of the consolidations into the peripheral ground glass and reticular opacity seen in the mid and lower zones bilaterally with score 3 . 


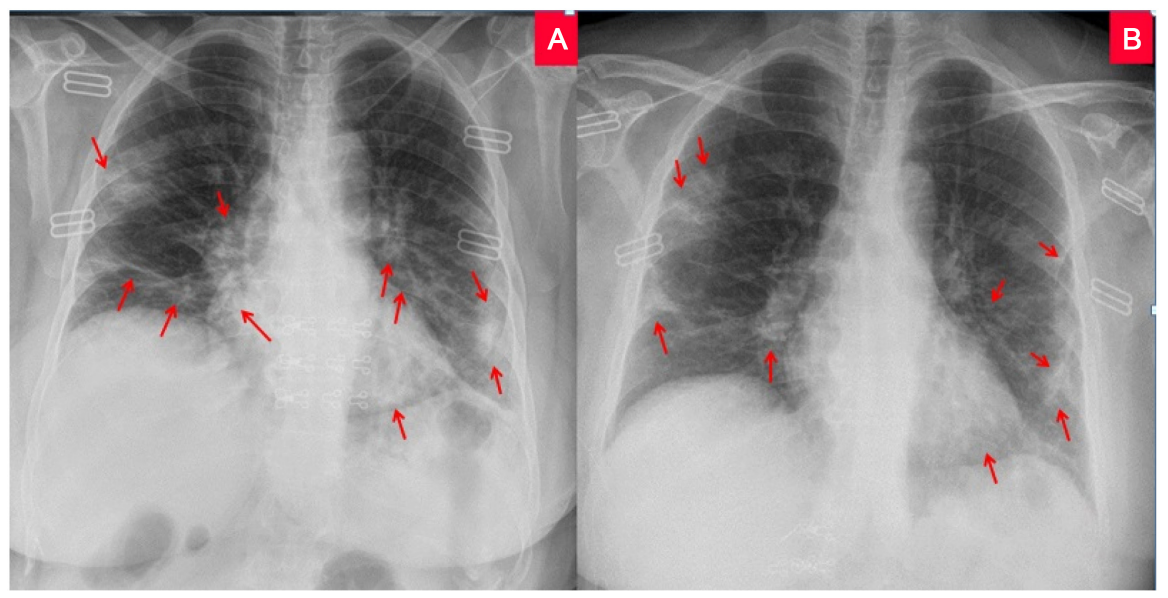

Figure 3. Two chest x-rays in a 54-year-old woman with COVID-19. (A): PA chest x-ray obtained on day 3illness shows bilateral peripheral lower zone ground glass opacity and consolidation with score 4; (B): PA chest x-ray obtained on day 12 illness shows remaining few bilateral middle and lower zone ground-glass opacity which are seen at peripheral regions with regression course and score 4.

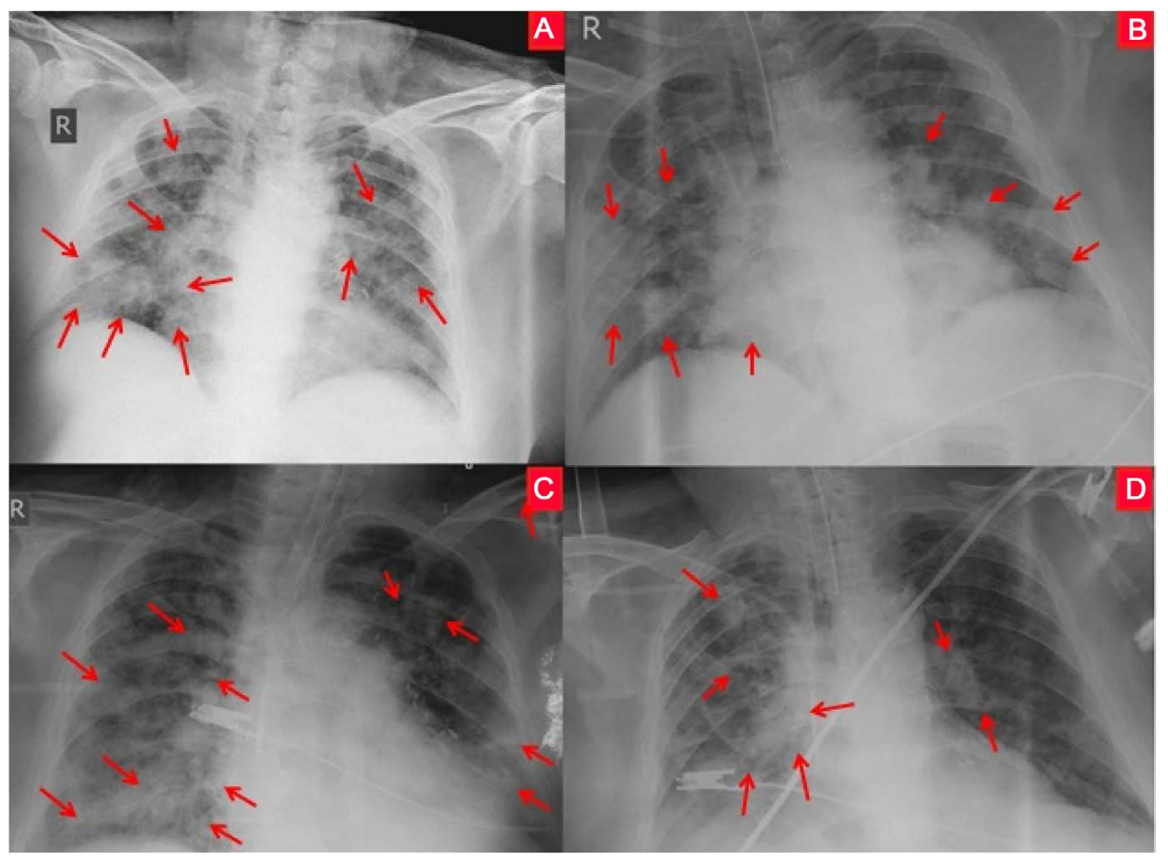

Figure 4. Series of chest $x$-rays in a 68-year-old man with COVID-19. (A): AP chest x-ray obtained on day 4 illness shows diffuse bilateral ground-glass opacity with multifocal central and peripheral nodular patchy consolidation with score 6; (B): AP chest x-ray obtained on day 6 illness shows progression course and diffuse bilateral ground-glass opacity with multifocal central and peripheral nodular patchy consolidation with score 6; (C): AP chest $x$-ray obtained on day 10illness shows the same degree of lung involvement; bilateral diffuse patch consolidation affecting both lung fields with score 6; (D): AP chest $\mathrm{x}$-ray obtained on day 13 illness shows remaining bilateral diffuse patch consolidation affecting both lung fields, more to the right.

$19.9 \%)$ than central distribution (7/136, 5.1\%), whereas lower zone location $(23 / 136,16.9 \%)$ was the most frequent location for opacity. Bilateral involvement 


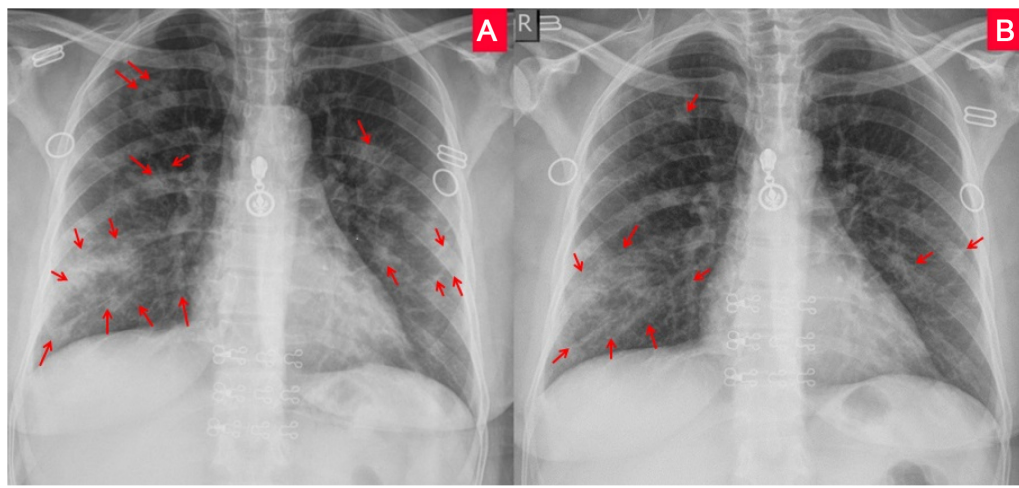

Figure 5. Two chest $x$-rays in a 40-year-old woman with COVID-19. (A): PA chest $\mathrm{x}$-ray obtained on day 7 illness shows right upper, middle, and lower zone ground-glass opacity with peripheral lower zone consolidation, left middle and lower zone ground-glass opacity and small nodular patches with score 5; (B): PA chest $\mathrm{x}$-ray obtained on day 13 illness shows right upper, middle, and lower zone ground-glass opacity with peripheral lower zone consolidation. Also, mild improvement is noted with score 3 .

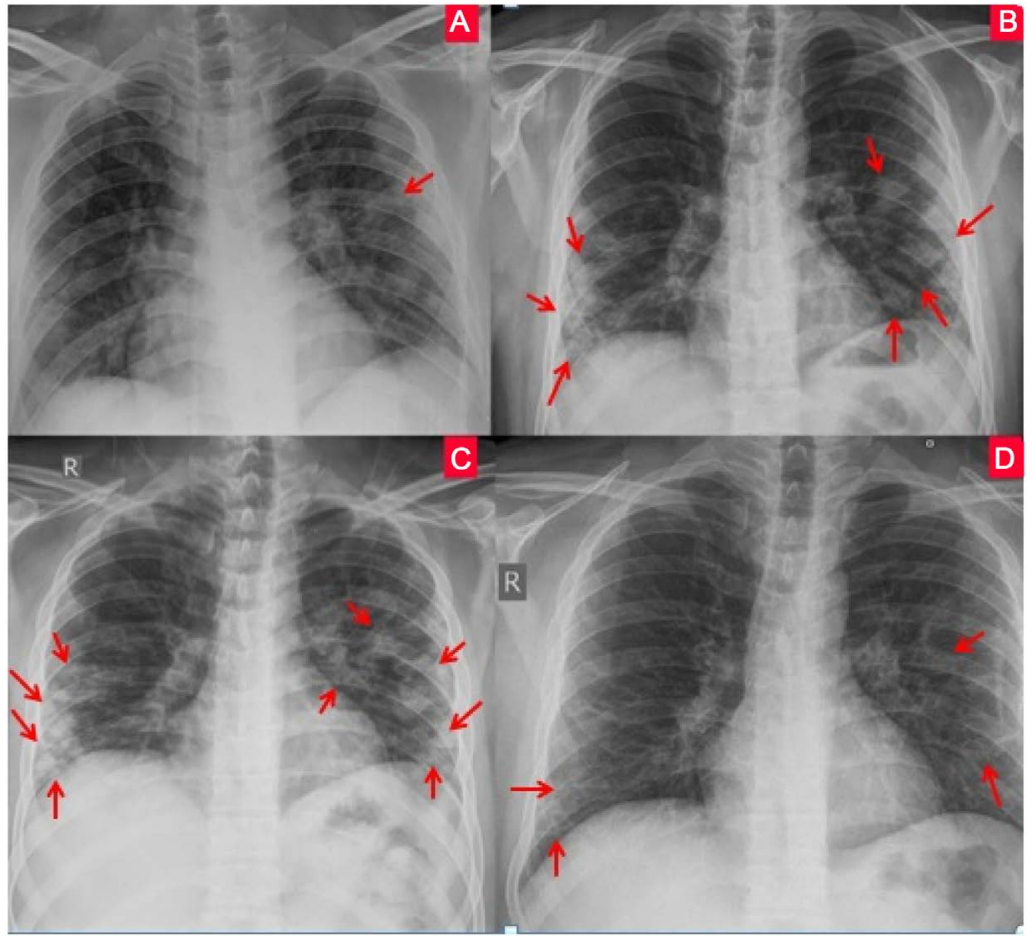

Figure 6. Series of chest $x$-rays in a 33-year-old man with COVID-19. (A): PA chest $\mathrm{x}$-ray obtained on day 4 illness shows bilateral ground-glass opacity with nodular patches at mid and lower zones, central in a location with score 4; (B): PA chest $\mathrm{x}$-ray obtained on day 8 illness shows remaining bilateral groundglass opacity with nodular patches at mid and lower zones, medial and peripheral in a location with score 4 too; (C): PA chest x-ray obtained on day 13 illness shows bilateral ground-glass opacity at mid and lower zones, central and peripheral in location with lesser extent compared with A and B with score 5; (D): PA chest $\mathrm{x}$-ray obtained on illness day 21 shows good improvement; the dissipative stage of mild bilateral trabecular reticular opacity pattern with minimal left peripheral ground-glass opacity with score 1 . 
Table 2. Radiological findings and monitoring characteristics at presentation.

\begin{tabular}{|c|c|c|c|c|}
\hline Parameter & $\begin{array}{l}\text { 1st CXR Imaging } \\
\mathrm{N}(\%)\end{array}$ & $\begin{array}{c}\text { 2nd CXR Imaging } \\
\mathrm{N}(\%)\end{array}$ & $\begin{array}{c}\text { 3rd CXR Imaging } \\
\mathrm{N}(\%)\end{array}$ & $\begin{array}{c}\text { 4th CXR Imaging } \\
\mathrm{N}(\%)\end{array}$ \\
\hline \multicolumn{5}{|l|}{ 6-point radiological opacity score } \\
\hline zero score & $81(59.6 \%)$ & $32(23.5 \%)$ & $4(2.9 \%)$ & $0(0 \%)$ \\
\hline 1 score & $6(4.4 \%)$ & $3(2.2 \%)$ & $0(0 \%)$ & $1(0.7 \%)$ \\
\hline 2 score & $21(15.4 \%)$ & $5(3.7 \%)$ & $2(1.5 \%)$ & $3(2.2 \%)$ \\
\hline 3 score & $6(4.4 \%)$ & $3(2.2 \%)$ & $3(2.2 \%)$ & $0(0 \%)$ \\
\hline 4 score & $11(8.1 \%)$ & $10(7.4 \%)$ & $5(3.7 \%)$ & $2(1.5 \%)$ \\
\hline 5 score & $7(5.1 \%)$ & $5(3.7 \%)$ & $2(1.5 \%)$ & $1(0.7 \%)$ \\
\hline 6 score & $4(2.9 \%)$ & $5(3.7 \%)$ & $4(2.9 \%)$ & $1(0.7 \%)$ \\
\hline \multicolumn{5}{|l|}{ Predominant pattern } \\
\hline \multicolumn{5}{|l|}{ Negative CxR } \\
\hline Normal & $81(59.6 \%)$ & $32(23.5 \%)$ & $4(2.9 \%)$ & $0(0 \%)$ \\
\hline Normal with increased & $74(54.4 \%)$ & $29(21.3 \%)$ & $4(2.9 \%)$ & $0(0 \%)$ \\
\hline Broncho vascular markings & $7(5.1 \%)$ & $3(2.2 \%)$ & $0(0 \%)$ & $0(0 \%)$ \\
\hline \multicolumn{5}{|l|}{ Positive CxR } \\
\hline Abnormal opacity & $55(40.4 \%)$ & $31(22.8 \%)$ & $16(11.8 \%)$ & $8(5.9 \%)$ \\
\hline $\begin{array}{l}\text { CxR by days (from the day of previous CxR) } \\
\text { Mean } \pm(\mathrm{SD})\end{array}$ & $7.2 \pm(4.75)$ & $4.5 \pm(5.83)$ & $1.4 \pm(4.28)$ & $0.96 \pm(4.27)$ \\
\hline \multicolumn{5}{|l|}{ Positive CxR finding } \\
\hline consolidation opacity & $21(15.4 \%)$ & $21(15.5 \%)$ & $10(7.3 \%)$ & $4(3 \%)$ \\
\hline \multicolumn{5}{|l|}{ consolidation classification } \\
\hline No consolidation & $115(84.6 \%)$ & $42(30.9 \%)$ & $10(7.4 \%)$ & $4(2.9 \%)$ \\
\hline Lobar & $9(6.6 \%)$ & $10(7.4 \%)$ & $4(2.9 \%)$ & $2(1.5 \%)$ \\
\hline Diffuse & $6(4.4 \%)$ & $5(3.7 \%)$ & $3(2.2 \%)$ & $2(1.5 \%)$ \\
\hline Multifocal & $6(4.4 \%)$ & $6(4.4 \%)$ & $3(2.2 \%)$ & $0(0 \%)$ \\
\hline Ground glass opacity & $46(33.8 \%)$ & $28(20.6 \%)$ & $12(8.8 \%)$ & $5(3.7 \%)$ \\
\hline Nodular opacity & $8(5.9 \%)$ & $7(5.1 \%)$ & $5(3.7 \%)$ & $1(0.7 \%)$ \\
\hline Reticular opacity & $6(4.4 \%)$ & $7(5.1 \%)$ & $7(5.1 \%)$ & $3(3.3 \%)$ \\
\hline Reticulonodular opacities & $3(2.2 \%)$ & $3(2.2 \%)$ & $7(5.1 \%)$ & $0(0 \%)$ \\
\hline \multicolumn{5}{|l|}{ Opacity side } \\
\hline Unilateral & $11(8.1 \%)$ & $5(3.7 \%)$ & $1(0.7 \%)$ & $1(0.7 \%)$ \\
\hline Bilateral & $43(31.6 \%)$ & $29(21.3 \%)$ & $14(10.3 \%)$ & $7(5.1 \%)$ \\
\hline No opacity & $82(60.3 \%)$ & $29(21.3 \%)$ & $5(3.7)$ & $0(0 \%)$ \\
\hline \multicolumn{5}{|l|}{ Opacity Location } \\
\hline No zone & $81(59.6 \%)$ & $29(21.3 \%)$ & $5(3.7 \%)$ & $0(0 \%)$ \\
\hline mid zone & $0(0 \%)$ & $1(0.7 \%)$ & $0(0 \%)$ & $0(0 \%)$ \\
\hline lower zone & $23(16.9 \%)$ & $8(5.9 \%)$ & $1(0.7 \%)$ & $2(1.5 \%)$ \\
\hline mid + lower zone & $22(16.2 \%)$ & $14(10.3 \%)$ & $7(5.1 \%)$ & $4(2.9 \%)$ \\
\hline upper + mid + lower zone & $10(7.4 \%)$ & $10(7.4 \%)$ & $7(5.1 \%)$ & $2(1.5 \%)$ \\
\hline \multicolumn{5}{|l|}{ Opacity Distribution } \\
\hline central & $7(5.1 \%)$ & $3(2.2 \%)$ & $1(0.7 \%)$ & $0(0 \%)$ \\
\hline peripheral & $27(19.9 \%)$ & $11(8.1 \%)$ & $4(2.9 \%)$ & $3(2.2 \%)$ \\
\hline peripheral + center & $22(16.2 \%)$ & $21(15.4 \%)$ & $11(8.1 \%)$ & $5(3.7 \%)$ \\
\hline No opacity & $80(58.8 \%)$ & $28(20.6 \%)$ & $4(2.9 \%)$ & $0(0 \%)$ \\
\hline \multicolumn{5}{|l|}{ Associated Finding } \\
\hline pleural effusion & $1(0.7 \%)$ & $1(0.7 \%)$ & $1(0.7 \%)$ & $0(0 \%)$ \\
\hline cardiomegaly & $1(0.7 \%)$ & $2(1.5 \%)$ & $0(0 \%)$ & $1(0.7 \%)$ \\
\hline pericardial effusion & $1(0.7 \%)$ & $0(0 \%)$ & $0(0 \%)$ & $0(0 \%)$ \\
\hline No associated findings & $133(97.8 \%)$ & $61(44.9 \%)$ & $17(12.5 \%)$ & $5(3.7 \%)$ \\
\hline
\end{tabular}


(43/136, 31.6\%) was noticed more than unilateral involvement (11/136, 8.1\%). An associated Pleural effusion was found in one patient $(0.7 \%)$. Similarly, cardiomegaly and pericardial effusion were found in one patient $(0.7 \%)$. The 6-point severity score showed that score zero, negative result, was the highest percentage $(81 / 136,59.6 \%)$, followed by score 2 , mild opacity changes, $(21 / 136$, $15.4 \%)$.

\subsubsection{Second Chest X-Ray Features Analysis}

Similar to the first chest X-ray features, the ground-glass opacity was the most common finding $(28 / 136,20.6 \%)$ during the second chest X-ray performance, followed by consolidation opacity $(23 / 136,16.9 \%)$ which was distributed as (10/136, 7.4\%) lobar, $(5 / 136,3.7 \%)$ diffuse, and $(6 / 136,4.4 \%)$ multifocal. The existence of simultaneous peripheral and central opacity was the highest reported percentage $(21 / 136,15.4 \%)$ compared to central $(3 / 136,2.2 \%)$ and peripheral $(11 / 136,8.1 \%)$ alone.

The lower and mid-zone were the commonest locations for opacity (14/136, $10.3 \%)$ while bilateral involvement $(29 / 136,21.3 \%)$ was seen more frequently than unilateral distribution $(5 / 136,3.7 \%)$. The pleural effusion, as an associated finding, was found in one patient $(0.7 \%)$ whereas cardiomegaly was seen in two patients $(1.5 \%)$. Concerning the radiological 6-point severity score, the results showed the highest percentage in score zero, (negative result) $(32 / 136,23.5 \%)$ followed by score 4 , moderate opacity changes, $(10 / 136,7.4 \%)$.

\subsubsection{Third Chest X-Ray Features Analysis}

Regarding the third radiography, the ground-glass opacity was also the most common finding $(12 / 136,8.8 \%)$, followed by consolidation opacity $(10 / 136$, $7.4 \%)$ which was distributed as $(4 / 136,2.9 \%)$ lobar, $(3 / 136,2.2 \%)$ for diffuse and multifocal distribution. Concurrent peripheral and central opacities reached a high percentage in distribution $(11 / 136,8.1 \%)$ compared to central opacities $(1 / 136,0.7 \%)$ and peripheral $(4 / 136,2.9 \%)$ alone. Concurrent opacity along all lung zones (upper, mid, and lower) and concurrent opacity in the mid and lower zone had a similar percentage and was the most frequent (7/136, 5.1\%). Bilateral involvement $(14 / 136,10.3 \%)$ was more common than unilateral distribution $(1 / 136,0.7 \%)$. An associated pleural effusion was found in one patient $(0.7 \%)$. Using the 6-point radiological opacity severity score, the results revealed the same percentage $(4 / 136,2.9 \%)$ for score zero (negative result) and score 6 (severe opacity), followed by $(5 / 136,3.7 \%)$ for score 4 , moderate opacity changes.

\subsubsection{Fourth Chest X-Ray Features Analysis}

The fourth chest X-ray showed the same pattern of opacity frequency with a remarkable reduction in percentage, with the ground-glass opacity decreasing to (5/136, 3.7\%), followed by consolidation opacity (4/136, 2.9\%). Concerning the consolidation opacity, the images showed a similar distribution $(2 / 136,1.5 \%)$ for the lobar and diffuse opacities. Concurrent peripheral and central opacities reached a high percentage in distribution $(5 / 136,3.7 \%)$ but peripheral distribu- 
tion alone was reported in $(3 / 136,2.2 \%)$, while no central distribution was noticed. The lower and mid-zone $(4 / 136,2.9 \%)$ were the most common locations for opacity and bilateral involvement $(7 / 136,5.1 \%)$ was seen more than unilateral distribution $(1 / 136,0.7 \%)$. Cardiomegaly was found in one patient $(0.7 \%)$. Regarding the radiological opacity 6-point severity score, score 2, mild opacity changes, occupied the highest percentage $(3 / 136,2.2 \%)$ followed by score 4 , moderate opacity changes, $(2 / 136,1.5 \%)$.

\subsection{Relationship between Radiological Finding, Severity 6-Points Score, and Daily Monitoring (Table 3)}

In adjusted analyses, a significant association was noticed between the 6-point severity score and the day of COVID-19 illness in the first, second, third, and fourth chest X-ray (overall $\mathrm{P}$-value $=0.0001$ ).

In the first chest $\mathrm{X}$-ray, the negative results after the first 5 days were reported in $(25 / 66,37.9 \%)$ which decreased to $(4 / 5,80 \%)$ within 16 - 20 days. Concerning the 6-point severity score per day, a statistically significant relationship was reported between the first 5 days and 6 - 10 days of illness, and between the first 5 days and $11-15$ days ( $\mathrm{P}$-value $=0.0001$ and 0.002 respectively). After 5 days, the most common opacity was ground-glass opacity, which disappeared on day 21 of diagnosis, with a significant $\mathrm{P}$-value of 0.0001 .

In the second chest $\mathrm{X}$-ray, mild opacity changes (score 1 ) were reported in $(2 / 88,2.3 \%)$ after the first 5 days, while severe opacity changes (score 5 and score $6)$ were reported in $(1 / 8,12.5 \%)$ between 16 - 20 days. There was a statistically significant relationship between the first 5 days and other illness days ( $\mathrm{P}$-value $=$ $0.0001)$.

In the third chest X-ray, $(1 / 119,0.8 \%)$ of cases were diagnosed as mild opacity changes (score 2) after the first 5 days, with a similar distribution for severe opacity changes (score 6). After 16 - 20 days, the percentage of negative results $(1 / 2,50 \%)$ was the same as the mild opacity change score 2 . Using the 6-point severity score per day, a statistically significant P-value of 0.0001 was reported between all-day groups. After the first 5 days of diagnosis, the ground glass opacity was seen in $(2 / 119,1.7 \%)$, which disappeared after 21 days, with no statistically significant P-value of 0.400 with days. In the same line, consolidation after the first 5 days was observed in $(1 / 119,0.8 \%)$ while it disappeared after 21 days, with no statistically significant $\mathrm{P}$-value of 0.089 . The reticular and reticulonodular opacities had the same proportion $(1 / 2,50 \%)$ and they appeared from 16 to 25 days.

In the fourth chest $x$-ray, score 5 , score 6 , and score 2 had the same percentage $(1 / 3,33.3 \%$ for each) in the 6 - 10 days period. After 21 - 25 days, the chest X-ray had a score of 1 , mild opacity changes, (1/1, 100\%) while after 26 - 30 days, the score was $2(2 / 2,100 \%)(\mathrm{P}$-value $=0.0001$ between all-day groups $)$. After the first 6 - 10 days, the most common radiological finding was consolidation $(3 / 4,75 \%)$, with no statistically significant P-value of 0.356 with days. In the same line, 
Table 3. Relationship between radiological findings and monitoring per day.

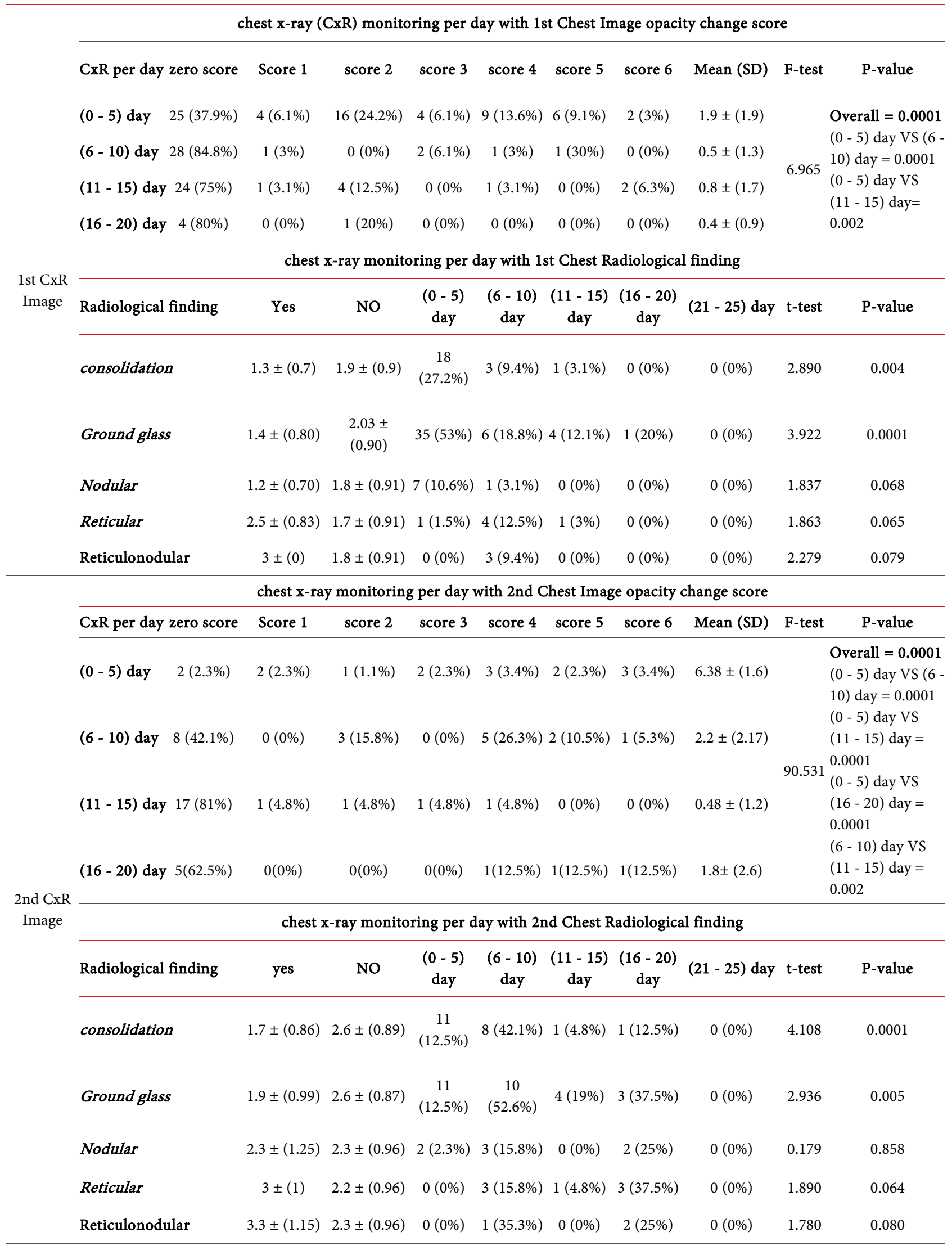




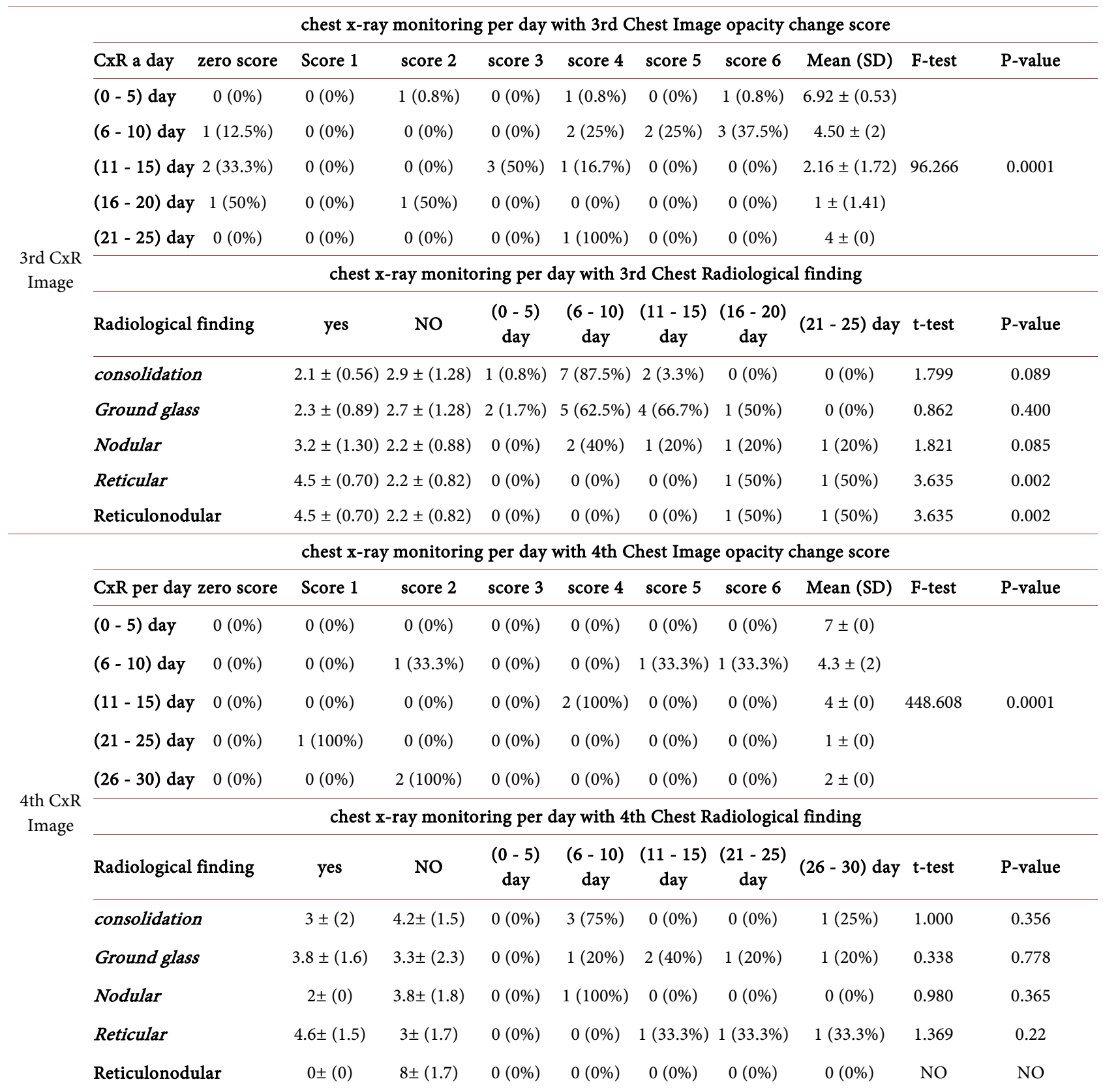

ground-glass opacity was seen in $(1 / 5,20 \%)$ after 6 - 10 days, then it became higher $(2 / 5,40 \%)$ after 11 - 15 days, and it was reported in (1/5, 20\%) after 16 30 days ( $\mathrm{P}$-value $=0.778$ with days).

\subsection{Correlation Age and Gender of the COVID-19 Patients with Radiological Findings (Table 4)}

\subsubsection{Age}

In the first chest $\mathrm{X}$-ray, a weak correlation was noticed between age groups and radiological findings while no correlation was noticed with nodular opacity $(\mathrm{r}=$ $0.158, \mathrm{P}$ value $=0.066)$. In the second chest $\mathrm{X}$-ray, a weak positive correlation 
Table 4. Correlation between radiological findings, score, age, and gender.

\begin{tabular}{|c|c|c|c|c|c|c|c|c|c|}
\hline \multicolumn{10}{|c|}{ 1st Chest Image } \\
\hline & & $\begin{array}{l}\text { Patient } \\
\text { gender }\end{array}$ & $\begin{array}{l}\text { Age } \\
\text { groups }\end{array}$ & $\begin{array}{c}\text { opacity } \\
\text { change score }\end{array}$ & consolidation & $\begin{array}{c}\text { Ground glass } \\
\text { opacity }\end{array}$ & $\begin{array}{c}\text { Nodular } \\
\text { opacity }\end{array}$ & $\begin{array}{c}\text { Reticular } \\
\text { opacity }\end{array}$ & $\begin{array}{l}\text { Reticulonodular } \\
\text { opacity }\end{array}$ \\
\hline \multirow{2}{*}{ Patient gender } & $\mathrm{R}$ & 1.000 & 0.000 & -0.159 & -0.072 & -0.152 & $-0.194^{*}$ & -0.055 & 0.013 \\
\hline & $\mathrm{P}$-value & & 0.996 & 0.065 & 0.404 & 0.076 & 0.064 & 0.521 & 0.881 \\
\hline \multirow{2}{*}{$\begin{array}{l}\text { Age classifications } \\
\text { groups }\end{array}$} & $\mathrm{R}$ & 0.000 & 1.000 & $0.350^{*}$ & $0.305^{*}$ & $0.281^{*}$ & 0.158 & $0.184^{*}$ & $0.261^{\star}$ \\
\hline & $\mathrm{P}$-value & 0.996 & & 0.000 & 0.000 & 0.001 & 0.066 & 0.032 & 0.002 \\
\hline \multirow{2}{*}{$\begin{array}{l}\text { opacity change } \\
\text { score }\end{array}$} & $\mathrm{R}$ & -0.159 & $0.350^{*}$ & 1.000 & $0.581^{*}$ & $0.807^{\star}$ & $0.409^{*}$ & $0.198^{*}$ & $0.212^{*}$ \\
\hline & $\mathrm{P}$-value & 0.065 & 0.000 & & 0.000 & 0.000 & 0.000 & 0.021 & 0.013 \\
\hline \multirow{2}{*}{ consolidation } & $\mathrm{R}$ & -0.072 & $0.305^{\star}$ & $0.581^{*}$ & 1 & $0.277^{\star}$ & $0.314^{*}$ & 0.003 & 0.070 \\
\hline & p-value & 0.404 & 0.000312 & 0.000 & & 0.001 & 0.000 & 0.974 & 0.418 \\
\hline \multicolumn{10}{|c|}{ 2nd Chest Image } \\
\hline & & $\begin{array}{l}\text { Patient } \\
\text { gender }\end{array}$ & $\begin{array}{l}\text { Age } \\
\text { groups }\end{array}$ & $\begin{array}{c}\text { opacity } \\
\text { change score }\end{array}$ & consolidation & $\begin{array}{c}\text { Ground glass } \\
\text { opacity }\end{array}$ & $\begin{array}{c}\text { Nodular } \\
\text { opacity }\end{array}$ & $\begin{array}{l}\text { Reticular } \\
\text { opacity }\end{array}$ & $\begin{array}{c}\text { Reticulonodular } \\
\text { opacities }\end{array}$ \\
\hline \multirow{2}{*}{ Patient gender } & $\mathrm{R}$ & 1.000 & 0.000 & $-0.203^{*}$ & 0.083 & 0.137 & 0.140 & 0.154 & $0.186^{*}$ \\
\hline & $\mathrm{P}$-value & & 0.996 & 0.018 & 0.340 & 0.113 & 0.103 & 0.073 & 0.030 \\
\hline \multirow{2}{*}{$\begin{array}{l}\text { Age classifications } \\
\text { groups }\end{array}$} & $\mathrm{R}$ & 0.000 & 1.000 & -0.116 & $0.219^{*}$ & $0.247^{* *}$ & $0.180^{*}$ & $0.204^{*}$ & $0.177^{\star}$ \\
\hline & P-value & 0.996 & & 0.178 & 0.010 & 0.004 & 0.036 & 0.017 & 0.040 \\
\hline \multirow{2}{*}{$\begin{array}{l}\text { opacity change } \\
\text { score }\end{array}$} & $\mathrm{R}$ & $-0.203^{*}$ & -0.116 & 1.000 & $0.824^{\star}$ & $0.829^{*}$ & $0.901^{\star}$ & $0.917^{\star}$ & $0.906^{*}$ \\
\hline & $\mathrm{P}$-value & 0.018 & 0.178 & & 0.0001 & 0.0001 & 0.000 & 0.000 & 0.000 \\
\hline \multirow{2}{*}{ consolidation } & $\mathrm{R}$ & 0.083 & $0.219^{*}$ & $0.824^{*}$ & 1 & $0.944^{*}$ & $0.936^{*}$ & $0.924^{*}$ & $0.932^{*}$ \\
\hline & $\mathrm{p}$-value & 0.340 & 0.0103534 & 0.0001 & & 0.0001 & 0.0001 & 0.0001 & 0.0001 \\
\hline \multicolumn{10}{|c|}{ 3rd Chest Image } \\
\hline & & $\begin{array}{l}\text { Patient } \\
\text { gender }\end{array}$ & $\begin{array}{l}\text { Age } \\
\text { groups }\end{array}$ & $\begin{array}{c}\text { opacity } \\
\text { change score }\end{array}$ & consolidation & $\begin{array}{c}\text { Ground glass } \\
\text { opacity }\end{array}$ & $\begin{array}{c}\text { Nodular } \\
\text { opacity }\end{array}$ & $\begin{array}{l}\text { Reticular } \\
\text { opacity }\end{array}$ & $\begin{array}{c}\text { Reticulonodular } \\
\text { opacities }\end{array}$ \\
\hline \multirow{2}{*}{ Patient gender } & $\mathrm{R}$ & 1.000 & 0.000 & 0.054 & -0.080 & -0.068 & -0.063 & -0.059 & -0.059 \\
\hline & p-value & & 0.996 & 0.532 & 0.356 & 0.432 & 0.469 & 0.498 & 0.498 \\
\hline \multirow{2}{*}{$\begin{array}{l}\text { Age classifications } \\
\text { groups }\end{array}$} & $\mathrm{R}$ & 0.000 & 1.000 & -0.167 & 0.165 & 0.167 & $0.172^{\star}$ & $0.171^{\star}$ & $0.171^{\star}$ \\
\hline & p-value & 0.996 & & 0.052 & 0.055 & 0.051 & 0.045 & 0.047 & 0.047 \\
\hline \multirow{2}{*}{$\begin{array}{l}\text { opacity change } \\
\text { score }\end{array}$} & $\mathrm{R}$ & 0.054 & -0.167 & 1.000 & $0.987^{*}$ & $0.990^{*}$ & $0.992^{*}$ & $0.995^{\star}$ & $0.995^{*}$ \\
\hline & p-value & 0.532 & 0.052 & & 0.0001 & 0.0001 & 0.0001 & 0.0001 & 0.0001 \\
\hline \multirow{2}{*}{ consolidation } & $\mathrm{R}$ & -0.080 & 0.165 & $0.987^{*}$ & 1 & $0.996^{*}$ & $0.994^{*}$ & $0.994^{*}$ & $0.994^{*}$ \\
\hline & $\mathrm{p}$-value & 0.356 & 0.055 & 0.0001 & & 0.0001 & 0.0001 & 0.0001 & 0.0001 \\
\hline \multicolumn{10}{|c|}{ 4th Chest Image } \\
\hline & & $\begin{array}{l}\text { Patient } \\
\text { gender }\end{array}$ & $\begin{array}{l}\text { Age } \\
\text { groups }\end{array}$ & $\begin{array}{c}\text { opacity } \\
\text { change score }\end{array}$ & consolidation & $\begin{array}{c}\text { Ground glass } \\
\text { opacity }\end{array}$ & $\begin{array}{l}\text { Nodular } \\
\text { opacity }\end{array}$ & $\begin{array}{l}\text { Reticular } \\
\text { opacity }\end{array}$ & $\begin{array}{c}\text { Reticulonodular } \\
\text { opacities }\end{array}$ \\
\hline \multirow{2}{*}{ Patient gender } & $\mathrm{R}$ & 1.000 & 0.000 & 0.064 & -0.068 & -0.063 & -0.066 & -0.063 & -0.065 \\
\hline & $\mathrm{p}$-value & & 0.996 & 0.462 & 0.429 & 0.469 & 0.442 & 0.469 & 0.455 \\
\hline \multirow{2}{*}{$\begin{array}{l}\text { Age classifications } \\
\text { groups }\end{array}$} & $\mathrm{R}$ & 0.000 & 1.000 & -0.098 & 0.099 & 0.101 & 0.098 & 0.10 & 0.10 \\
\hline & $\mathrm{p}$-value & 0.996 & & 0.257 & 0.253 & 0.242 & 0.257 & 0.234 & 0.253 \\
\hline \multirow{2}{*}{$\begin{array}{l}\text { opacity change } \\
\text { score }\end{array}$} & $\mathrm{R}$ & 0.064 & -0.098 & 1.000 & $0.999^{*}$ & $0.999^{*}$ & $0.999^{*}$ & $0.999^{*}$ & $0.999^{*}$ \\
\hline & $\mathrm{p}$-value & 0.462 & 0.257 & & 0.0001 & 0.0001 & 0.0001 & 0.0001 & 0.0001 \\
\hline \multirow{2}{*}{ consolidation } & $\mathrm{R}$ & -0.068 & 0.099 & $0.999^{*}$ & 1 & $0.998^{*}$ & $1.000^{*}$ & $0.998^{*}$ & $1.000^{*}$ \\
\hline & $\mathrm{p}$-value & 0.429 & 0.253 & 0.0001 & & 0.0001 & 0.0001 & 0.0001 & 0.0001 \\
\hline
\end{tabular}

${ }^{*}$ Significant correlation. 
was observed between age and radiological findings. In the third chest $\mathrm{x}$-ray, no correlation was observed between age and consolidation opacity ( $\mathrm{P}$-value $=$ $0.055)$ and with ground-glass opacity $(\mathrm{P}$-value $=0.051)$. Also, no correlation was seen in fourth chest $\mathrm{x}$-ray between age and radiological findings $(\mathrm{P}$-value $>0.05)$.

\subsubsection{Gender}

The results showed no statistically significant correlation between patients' gender and all radiological findings (see Table 4 for details).

\section{Discussion}

Chest X-ray is a critical tool for assessment of the lung opacity changes due to its wide availability, rapid performance, and acquisition at the ill patient's bed along with the portable machines which limit the risk of cross-infection [9] [16]. Based on the risks of misdiagnosis and viral transmission, the American College of Radiology (ACR) recommends that CT should not be used as a screening tool or as a first-line test to diagnose COVID-19. Instead, CT should be reserved for hospitalized, symptomatic patients with specific clinical indications [9].

In Gaza strip, the prevalence of COVID-19 is surging day after day [5]. The 6-point radiological scoring system is aimed at assessment of the severity and progression of lung changes in chest X-ray among hospitalized patients.

In our case series study, we assessed the radiological lung changes by monitoring chest radiographs, up to four images during various phases of illness in COVID 19 patients. During our continuous assessment, a regression course to improvement was noticed over the time course of illness. Of 136 cases, (55/136, $40.4 \%$ ) cases had positive radiological lung changes within an average of one-week (7.2 \pm (4.75) days from the time of COVID-19 confirmed diagnosis. The percentage of positive radiological lung opacity changes decreased to $(31 / 136,22.8 \%)$ for patients who underwent the second chest X-ray within an average of $4.5 \pm$ (5.83) days after the first chest X-ray. The percentage of positive radiological lung changes opacity significantly decreased to $(8 / 136,5.9 \%)$ throughout the course of illness. This trend explains the regression course of lung changes opacity and improvement COVID-19 patients over the course of illness.

Our results showed peripheral and lower zone opacity as the most frequent sites for opacity in COVID-19 patients, and this is consistent with a study conducted by Wong et al. (2020) [17]. However, there is inconsistency regarding the most common radiological finding. Our results revealed ground-glass opacity to be the most common finding with a decreasing trend over the time course (from $33.8 \%$ in the first Chest X-ray to $3.7 \%$ in the fourth chest X-ray), followed by consolidation (from $16.2 \%$ in the first Chest X-ray to $2.9 \%$ in the fourth chest C-ray). This is consistent with another study performed by Wang et al. (2020) [18] which concluded: "the predominant pattern of abnormalities after symptom onset was ground-glass opacity ( $45 \%$ to $62 \%$ in different periods)". On the other hand, Wong et al. (2020) [17] demonstrated consolidation as the most common 
finding (47\%), followed by ground-glass opacities (33\%). Similarly, Yoon et al. (2019) [12] study, which was conducted on a small case series in Korea, reported consolidation as the most frequent (70\%) radiological finding.

In this study, the highest percentage in all image series at different periods of illness was bilateral distribution (31.6\%) compared to (8.1\%) unilateral opacity. This is consistent with Rodriguez-Morales et al. (2020) [19], which illustrated that bilateral lung involvement was the most common distribution (72.9\%) whereas unilateral opacity was found in $25 \%$ of cases. The chest radiograph is the best tool for monitoring the track of lung opacity changes in different periods. The current results showed that the development of opacity starts from the first 7 days as a ground-glass opacity then converts into consolidation, with white irregular patchy and air bronchogram sign, from 5 - 20 days. This is consistent with the progressive opacities and consolidation that have been observed on chest radiographs over the time course of the illness in Shi et al study [20].

In mild illness, the 6-point radiological severity score did not exceed score 2 in the first 5 days, but in moderate illness, the score reached a maximum of 4 after two weeks. On the other hand, the score reached 6 in severe illness within 14 to 20 days from the time of confirmed diagnosis. The rounded or irregular opacity with well-defined edges is frequently associated with viral pneumonia [21] [22]. In our study, the conversion of consolidation together with ground glass into nodular patchy opacity was observed within $6-15$ days in $10.6 \%$ of cases. This is similar to Ai T et al. (2019) [23] [24] findings which reported that 3\% - 13\% of COVID-19 patients appear with multifocal solid irregular nodules.

The reticular pattern is the pathological process in the pulmonary interstitium and is characterized by interlobular septal thickening and prominent interlobular lines [25]. The reported prevalence of reticular pattern and linear opacification is very variable in the literature and has been reported between $1 \%$ and $81 \%$ [26]. In this study, we detected this pattern of lung opacity from day 16 to 25 at 33\%. This was consistent with Xiong et al. (2020) and Lei et al. (2019) [25] [26], in which reticular pattern was usually seen in COVID-19 patients with longer disease course.

The reticulonodular opacity, which indicates a dissipative phase (2 - 3 weeks after the onset of symptoms) is characterized by reticular pattern, mesh-like thickening of the interlobular septa, sporadic coherent opacities, reticular opacities, and bronchial wall thickening after 2 weeks [24] [27]. A significant direct correlation was found between the 6-point chest $\mathrm{x}$-ray severity score and major lung opacities (consolidation and ground glass).

On the other hand, no significant correlation was seen in our study between the gender of COVID-19 patients and opacity change score (P-value $>0.05$ ). This reflects no discrepancies in severity between males and females infected with Coronavirus disease. Additionally, a weak direct correlation was noticed between the COVID-19 patient's age and the severity score in the first Chest $\mathrm{X}$-ray $(\mathrm{r}=0.350, \mathrm{P}$-value $=0.0001)$ while no correlation was seen between age and opacity change score in the second, third, and fourth Chest X-ray (P-value = 
0.178., 0.052 and 0.257 respectively).

\section{Conclusion}

To conclude, the lung changes observed in chest X-ray of COVID-19 patients may vary depending on the stage of the disease. Generally, a wide spectrum of changes and locations was noticed, from pure ground-glass, mixed ground-glass opacities and consolidation type to a dissipative stage, and from bilateral and peripheral involvement to the unilateral, middle, and lower zone opacity. We emphasize the 6-point-scoring system as a promising tool in monitoring the radiological changes due to its ability to provide correlation with the disease progression or regression pathway over the course of illness, its simplicity, and easy replicability in any hospital.

\section{Acknowledgements}

Thank you to Dr/Nahed al Laham, Dr/Walaa Mousa, and Mr/Suliman Higazy. Additionally, we would like to thank Valley Fever Institute, UCLA Kern Medical, Bakersfield, California, USA for English language editing. We thank Palestinian American Medical Association (PAMA) members for their encouragement and contribution to this paper.

\section{Conflicts of Interest}

The authors declare no conflicts of interest regarding the publication of this paper.

\section{Funding}

This paper has received funding from Palestinian American Medical Association (PAMA).

\section{References}

[1] Wang, C., Horby, P.W., Hayden, F.G. and Gao, G.F. (2020) A Novel Coronavirus Outbreak of Global Health Concern. The Lancet, 395, 470-473. https://doi.org/10.1016/S0140-6736(20)30185-9

[2] Chen, N., Zhou, M., Dong, X., Qu, J., Gong, F., Han, Y., et al. (2020) Epidemiological and Clinical Characteristics of 99 Cases of 2019 Novel Coronavirus Pneumonia in Wuhan, China: A Descriptive Study. The Lancet, 395, 507-513. https://doi.org/10.1016/S0140-6736(20)30211-7

[3] Palestinian Central Bureau of Statistics (PCBS) (2019) About 13 Million Palestinians in the Historical Palestine and Diaspora. Ramallah: Palestinian Central Bureau of Statistics. http://www.pcbs.gov.ps/post.aspx?lang=en\&ItemID=3503

[4] Palestinian National Authority Ministry of Health Unit of Information System (2020) Daily Report for COVID-19 Virus.

http://www.moh.gov.ps/portal/wp-content/uploads/2020/08/Cor.Eng_.25-8-2020.p df

[5] Palestinian National Authority Ministry of Health Unit of Information System (2020) Daily report for COVID-19 Virus. 
http://www.moh.gov.ps/portal/wp-content/uploads/2020/12/Cor.-Eng-27-12.pdf

[6] Chung, M., Bernheim, A., Mei, X., Zhang, N., Huang, M., Zeng, X., et al. (2020) CT Imaging Features of 2019 Novel Coronavirus (2019-nCoV). Radiology, 295, 202-207. https://doi.org/10.1148/radiol.2020200230

[7] Ng, M.Y., Lee, E.Y., Yang, J., Yang, F., Li, X., Wang, H., et al. (2020) Imaging Profile of the COVID-19 Infection: Radiologic Findings and Literature Review. Radiology. Cardiothoracic Imaging, 2, e200034. https://doi.org/10.1148/ryct.2020200034

[8] Pan, F., Ye, T., Sun, P., Gui, S., Liang, B., Li, L., et al. (2020) Time Course of Lung Changes on Chest CT during Recovery from 2019 Novel Coronavirus (COVID-19) Pneumonia. Radiology, 295, 715-721. https://doi.org/10.1148/radiol.2020200370

[9] American College of Radiology (2020) ACR Recommendations for the Use of Chest Radiography and Computed Tomography for suspected COVID-19 Infection. https://www.acep.org/corona/covid-19-field-guide/assessment/chest-x-ray-and-ct/

[10] de Barry, O., Obadia, I., El Hajjam, M., Carlier, R.Y. and Hajjam, M.E. (2020) Chest-X-Ray Is a Mainstay for Follow-up in Critically Ill Patients with Covid-19 Induced Pneumonia. European Journal of Radiology, 129, Article ID: 109075. https://doi.org/10.1016/j.ejrad.2020.109075

[11] Chakraborty, S., Kritya, M., Aundhekar, A. and Aiyer, A. (2020) Chest Imaging in COVID-19. Praxis Undergraduate Medical Research Journal, 3, Article No. 86. http://www.praxisug.com/index.php/Praxis/article/view/86

[12] Yoon, S.H., Lee, K.H., Kim, J.Y., Lee, Y.K., Ko, H., Kim, K.H., et al. (2020) Chest Radiographic and CT Findings of the 2019 Novel Coronavirus Disease (COVID-19): Analysis of Nine Patients Treated in Korea. Korean Journal of Radiology, 21, 494-500. https://doi.org/10.3348/kjr.2020.0132

[13] Giovagnoni, A. (2020) Facing the COVID-19 Emergency: We Can and We Do. La radiologia medica, 125, 337-338. https://doi.org/10.1007/s11547-020-01178-y

[14] Jacobi, A., Chung, M., Bernheim, A. and Eber, C. (2020) Portable Chest X-Ray in Coronavirus Disease-19 (COVID-19): A Pictorial Review. Clinical Imaging, 64, 35-42. https://doi.org/10.1016/j.clinimag.2020.04.001

[15] Toussie, D., Voutsinas, N., Finkelstein, M., Cedillo, M. A., Manna, S., Maron, S. Z., et al. (2020) Clinical and Chest Radiography Features Determine Patient Outcomes in Young and Middle-Age Adults with COVID-19. Radiology, 297, E197-E206. https://doi.org/10.1148/radiol.2020201754

[16] Cozzi, D., Albanesi, M., Cavigli, E., Moroni, C., Bindi, A., Luvarà, S., et al. (2020) Chest X-Ray in New Coronavirus Disease 2019 (COVID-19) Infection: Findings and Correlation with Clinical Outcome. La Radiologia Medica, 125, 730-737. https://doi.org/10.1007/s11547-020-01232-9

[17] Wong, H.Y.F., Lam, H.Y.S., Fong, A.H.T., Leung, S.T., Chin, T.W.Y., Lo, C.S.Y., et al. (2020) Frequency and Distribution of Chest Radiographic Findings in COVID-19 Positive Patients. Radiology, 296, E72-E78. https://doi.org/10.1148/radiol.2020201160

[18] Wang, Y., Dong, C., Hu, Y., Li, C., Ren, Q., Zhang, X., et al. (2020) Temporal Changes of CT Findings in 90 Patients with COVID-19 Pneumonia: A Longitudinal Study. Radiology, 296, E55-E64. https://doi.org/10.1148/radiol.2020200843

[19] Rodriguez-Morales, A.J., Cardona-Ospina, J.A., Gutiérrez-Ocampo, E., Villamizar-Peña, R., Holguin-Rivera, Y., Escalera-Antezana, J.P., et al. (2020) Clinical, 1Aboratory and Imaging Features of COVID-19: A Systematic Review and Meta-Analysis. Travel Medicine and Infectious Disease, 34, Article ID: 101623. 
https://doi.org/10.1016/j.tmaid.2020.101623

[20] Shi, H., Han, X., Jiang, N., Cao, Y., Alwalid, O., Gu, J., et al. (2020) Radiological Findings from 81 Patients with COVID-19 Pneumonia in Wuhan, China: A Descriptive Study. Lancet Infectious Diseases, 20, 425-434.

https://doi.org/10.3348/kjr.2020.0132

[21] Hansell, D.M., Bankier, A.A., MacMahon, H., McLoud, T.C., Muller, N.L. and Remy, J. (2008) Fleischner Society: Glossary of Terms for Thoracic Imaging. Radiology, 246, 697-722. https://doi.org/10.1148/radiol.2462070712

[22] Franquet, T. (2011) Imaging of Pulmonary Viral Pneumonia. Radiology, 260, 18-39. https://doi.org/10.1148/radiol.11092149

[23] Ai, T., Yang, Z., Hou, H., Zhan, C., Chen, C., Lv, W., et al. (2020) Correlation of Chest CT and RT-PCR Testing in Coronavirus Disease 2019 (COVID-19) in China: A Report of 1014 Cases. Radiology, 296, E32-E40. https://doi.org/10.1148/radiol.2020200642

[24] Pan, Y., Guan, H., Zhou, S., Wang, Y., Li, Q., Zhu, T., et al. (2020) Initial CT Findings and Temporal Changes in Patients with the Novel Coronavirus Pneumonia (2019-nCoV): A Study of 63 Patients in Wuhan, China. European Radiology, 30, 3306-3309. https://doi.org/10.1007/s00330-020-06731-X

[25] Xiong, Y., Sun, D., Liu, Y., Fan, Y., Zhao, L., Li, X. and Zhu, W. (2020) Clinical and High-Resolution CT Features of the COVID-19 Infection: Comparison of the Initial and Follow-Up Changes. Investigative Radiology, 55, 332-339.

https://doi.org/10.1097/RLI.0000000000000674

[26] Lei, J., Li, J., Li, X. and Qi, X. (2020) CT Imaging of the 2019 Novel Coronavirus (2019-nCoV) Pneumonia. Radiology, 295, 18. https://doi.org/10.1148/radiol.2020200236

[27] Jin, Y.H., Cai, L., Cheng, Z.S., Cheng, H., Deng, T., Fan, Y.P., et al. (2020) A Rapid Advice Guideline for the Diagnosis and Treatment of 2019 Novel Coronavirus (2019-nCoV) Infected Pneumonia (Standard Version). Military Medical Research, 7, Article No. 4. https://doi.org/10.1186/s40779-020-0233-6 